\title{
ANALISIS NILAI-NILAI KEBANGSAAN DAN KEBHINEKAAN DI MADRASAH MADANI ALAUDDIN MAKASSAR
}

\author{
Muzakkir $^{1}$, Ali Umar Dani \\ Universitas Islam Negeri Alauddin Makassar \\ muzakkir.ftk@uin-alauddin.ac.id, ali.umardani@gmail.com
}

\begin{abstract}
This study aims to analyze the activities carried out in instilling the values of nationality and diversity in Madrasah Madani Alauddin Makassar. The process of data collection is done by the method of observation and interviews with students, teachers and principals. In the process of inculcating national values and diversity on students in the midst of globalization, this is done through various ways, through Civics learning in the classroom, extracurricular activities, and holding positive activities in schools to support the national spirit of the students. Supporting factors in instilling national values and diversity in students include the cooperation of schools, namely the principal and teachers in providing good examples or examples to students, students' interest in participating in extracurricular activities in schools, adequate facilities and infrastructure. Inhibiting factors in instilling the value of nationality in students include the character of students from different family backgrounds, and students have not been able to divide their time for activities in school properly. To overcome the obstacles in instilling national values and diversity in students is the teacher holding problem solving with efforts to motivate students to respect each other, the school the principal and the teacher conducts an evaluation every semester to students to see the development of students.
\end{abstract}

Keywords: Nationality Value, Diversity

\section{PENDAHULUAN}

Globalisasi memiliki peran sentral dalam meningkatkan gerakan-gerakan radikalisasi massa. Nilai-nilai kebangsaan dan kebhinekaan harus ditanamkan pada para peserta didik. Derasnya arus globalisasi menyebabkan nilai-nilai kebangsaan dapat dikatakan semakin dilupakan keberadaannya. Salah satu masalah utama adalah masalah identitas kebangsaan. Dengan derasnya arus globalisasi dikhawatirkan budaya bangsa khususnya nilai-nilai kebangsaan dan budaya lokal mulai terkikis. Budaya asing kian mewabah dan mulai mengikis eksitensi budaya bangsa dan nilai-nilai nasional yang sarat makna. Agar eksistensi budaya bangsa tetap kukuh diperlukan upaya mempertahankan identitas bangsa yang dikarenakan fenomena peserta didik lebih menyukai dan bangga dengan budaya budaya asing dari pada budaya asli bangsanya sendiri. Hal ini dibuktikan dengan adanya rasa bangga yang lebih pada diri anak manakala menggunakan produk luar negeri dibandingkan jika menggunakan produk bangsa sendiri. 
Generasi muda adalah salah satu aset Indonesia pada masa yang akan datang. Bangsa Indonesia harus mampu menempatkan generasinya untuk menjadi pemimpin di masa mendatang. Hal tersebut harus ada upaya untuk menanamkan nilai-nilai kebangsaan sebagai ciri khas budaya bangsa untuk membedakan dengan orang lain di negera ini. Selain itu adanya budaya lokal yang melekat pada diri peserta didik di sekolah akan mampu memperkuat jati diri sebagai bangsa Indonesia. Masalah ini merupakan suatu fakta yang tidak boleh diabaikan mengingat pentingnnya sikap nasionalisme dalam memajukan Negara Indonesia. Terkait dengan penanaman nilai kebangsaan di era global ini, salah satu lembaga formal yang ikut bertanggung jawab adalah satuan pendidikan formal yang turut membantu tugas pendidikan informal. Sekolah dapat dikatakan sebagai rumah kedua. Di sekolah dan asrama selain mendapatkan pendidikan akademik, peserta didik juga mendapatkan pendidikan moral dan spiritual, karena itu sekolah dan asrama menjadi salah satu wadah yang tepat untuk menanamkan nilai-nilai kebangsaan dan kebhinnekaan kepada peserta didik. Dalam hal ini guru dan pembina asrama mempunyai peran yang sangat penting.

Tujuan Penelitian ini untuk mendeskripsikan kegiatan yang dilakukan di Madrasah/ Pesantren Madani UIN Alauddin Makassar dalam menanamkan nilai-nilai kebangsaan dan kebhinnekaan.

\section{METODE PENELITIAN}

Metode yang digunakan dalam penelitian ini adalah metode observasi dan interview yaitu peneliti berusaha mendeskripsikan atau menggambarkan dan menginterprestasikan objek yang sedang berlangsung dengan tujuan membangun makna berdasarkan data lapangan. Penelitian ini dikategorikan penelitian lapangan yang prosedur penelitiannya dapat menghasilkan data dekriptif berupa kata-kata, data tertulis atau lisan dari orangorang dan pelaku yang diamati (diobservasi).

\section{KAJIAN TEORI}

\section{A. Penanaman Nilai-Nilai Kebangsaan dan Kebhinnekaan}

\section{Pengertian Nilai}

Nilai adalah konsep atau gagasan yang menyeluruh mengenai apa yang hidup dalam pikiran seseorang atau sebagian besar anggota masyarakat tentang apa yang dipandang baik, berharga, dan penting dalam hidup yang berfungsisebagai pedoman yang memberi arah dan orientasi kepada kehidupan manusia (Rukiyati, 2008: 62).

Menurut Kuoerman (Mulyana, 2004: 9) Nilai merupakan patokan normatif yang memengaruhi manusia dalam menentukan pilihannya di antara cara-cara tindakan alternatif, definisi ini memiliki tekanan utama pada norma sebagai faktor eksternal yang memengaruhi perilaku manusia. Jadi, salah satu bagian terpenting dalam proses pertimbangan nilai (value judgement) adalah pemeliharaan nilai-nilai normatif yang berlaku di masyarakat. 
Dari beberapa pengertian di atas dapat disimpulkan bahwa nilai adalah sifat atau kualitas yang melekat pada objek, bukan objek itu sendiri. Menilai berarti menimbang suatu kegiatan manusia untuk menghubungkan sesuatu dengan sesuatu yang lain, kemudian selanjutnya diambil keputusan.

Notonagoro (Rukiyati, 2008: 60) memandang bahwa ada tiga nilai yang yang perlu diperhatikan dan menjadi pegangan hidup manusia, yaitu (1) nilai material, (2) nilai vital, (3) nilai kerohanian. Nilai-nilai ini dijadikan landasan, alasan atau motivasi bagi manusia dalam menempatkan perbuatan. Keputusan seseorang untuk melakukan sesutau hal diambil dengan berdasarkan atas pertimbangan nilai yang dimilikinya.

\section{Nasionalisme}

Nasionalisme barasal dari kata Latin "nation" yang berarti "lahir" atau "kelahiraan". Dalam kehidupan berbangsa terdapat berbagai pengertian tentang nasionalisme. Ada yang memberikan arti sebagai kesadaran akan jati diri bangsa, ada pula yang mengartikannya sebagai suatu naluri introspeksi atau agresivitas. Nasionalisme bangsa Indonesia memiliki sikap yang sangat positif, yaitu mendorong terwujudnya negara Republik Indonesia yang bersatu, berdaulat, adil dan makmur. Di samping itu juga bertujuan untuk melindungi segenap bangsa Indonesia dan seluruh tumpah darah Indonesia, serta untuk memajukan kesejahteraan umum, mencerdaskan kehidupan bangsa dan turut serta melaksanakan ketertiban dunia yang berdasarkan kemerdekaan, perdamaian abadi dan keadilan sosial (Suprayogi 1992:5).

Berdasarkan pendapat di atas, jelaslah bahwa nasionalisme bangsa Indonesia bukanlah nasionalisme yang berkonotasi sempit, dan bukan pula nasionalisme yang menginginkan pengisolasian diri dari pergaulan dunia.

\section{Nilai-Nilai Kebangsaan}

Nilai-nilai yang dikembangkan dalam pendidikan nilai kebangsaan teridentifikasi sejumlah nilai sebagai berikut (Kemendiknas, 2010: 9-10).

1) Religius: Sikap dan perilaku yang patuh dalam melaksanakan ajaran agama yang dianutnya, toleran terhadap pelaksaan ibadah agama lain, dan hidup rukun dengan pemeluk agama lain.

2) Jujur: Perilaku yang didasarkan pada upaya menjadikan dirinya sebagai orang yang selalu dapat dipercaya dalam perkataan, tindakan, dan pekerjaan.

3) Toleransi: Sikap dan tindakan yang menghargai perbedaan agama, suku etnis, sikap, pandapat, dan tindakan orang lain yang berbeda darinya.

4) Disiplin: Tindakan yang menunjukkan perilaku tertib dan patuh pada berbagai ketentuan dan peraturan.

5) Mandiri: Sikap dan perilaku yang tidak mudah tergantung pada orang lain dalam menyelesaikan tugas.

6) Demokrasi: Cara berpikir, bersikap, dan bertindak yang menilai sama hak dan kewajiban dirinya dan orang lain. 
7) Rasa ingin tahu: Sikap dan tindakan yang selalu berupaya untuk mengetahui lebih mendalam dan meluas dari sesuatu yang dipelajari, dilihat, dan didengar.

8) Semangat kebangsaan: Cara berpikir, bertindak, dan berwawasan yang menempatkan kepentingan bangsa di atas kepentingan kelompok maupun individu.

9) Cinta tanah air: Cara berpikir, bersikap, dan berbuat yang menunjukkan kesetiaan, kepedulian, dan penghargaan tinggi terhadap bahasa, lingkungan fisik, sosial, budaya, ekonomi, dan politik bangsa.

10) Menghargai prestasi: Sikap dan tindakan yang mendorong dirinya untuk menghasilkan sesuatu yang berguna bagi masyarakat, dan mengakui, serta menghormati keberhasilan orang lain.

11) Peduli lingkungan: Sikap dan tindakan yang selalu berupaya mencegah kerusakan pada lingkungan alam disekitarnya, dan mengembangkan upayaupaya untuk memperbaiki kerusakana alam yang sudah terjadi.

12) Peduli sosial: Sikap dan tindakan yang selalu ingin memberi bantuan pada orang lain dan masyarakat yang membutuhkan.

13) Tanggung jawab: Sikap dan perilaku seseorang untuk melaksanakan tugas dan kewajibannya yang seharusnya dilakukan terhadap diri sendiri, masyarakat, lingkungan (alam, sosial, dan budaya), Negara dan Tuhan Yang Maha Esa

Nilai-nilai kebangsaan tersebut bersumber dan mengakar dalam budaya bangsa Indonesia dalam kehidupan bermasyarakat, berbangsa dan bernegara yang berwujud atau mewujudkan diri secara statis menjadi dasar negara, ideologi nasional dan jati diri bangsa, sedangkan secara dinamik menjadi semangat kebangsaan. Sebagai dasar negara, nilainilai kebangsaan tersebut melandasi segala kegiatan pemerintahan negara, baik dalam pengelolaan pemerintahan negara maupun dalam membangun hubungan dengan negaranegara lain. Nilai-nilai kebangsaan dalam hal ini juga menjadi etika bagi penyelenggara negara.

\section{B. Kebhinekaan}

Bhinneka Tunggal Ika yang dilembagakan dalam tata pemerintahan dan menjadi semboyan Negara Indonesia, cukup indah karena tidak hanya menjamin kesetaraan dalam kebhinnekaan agama, tetapi juga suku, ras maupun golongan di Indonesia, karena agama sering melekat dengan ketiganya. Konsep pendirian negara bangsa (nation state) oleh Sukarno menegaskan asas kesetaraan dalam ketatanegaraan, di mana setiap orang dijamin berkedudukan sama di hadapan hukum. Hal tersebut menguatkan konsensus pendiri bangsa sebelumnya bahwa Pancasila yang berjiwa inklusif sebagai dasar NKRI.

Prinsip Ketuhanan Yang Maha Esa dari Pancasila merupakan konseptualisasi dari kebebasan beragama di Indonesia. Karena setiap sila saling menjiwai, maka merangkul kemanusiaan, membangun persatuan, berdemokrasi, dan mewujudkan keadilan sosial adalah wujud ekspresi relijiusitas bangsa. Konsep kebebasan memilih agama begitu jelas difirmankan oleh Allah swt. sebagaimana disebutkan dalam Q.s. al-Baqarah/2: 256. 
Terjemahnya:Tidak ada paksaan dalam (menganut) agama (Islam), sesungguhnya telah jelas (perbedaan) antara jalan yang benar dengan jalan yang sesat. Barangsiapa ingkar kepada Thaghut dan beriman kepada Allah, maka sungguh, dia telah berpegang (teguh) pada tali yang sangat kuat yang tidak akan putus. Allah Maha Mendengar, Maha Mengetahui.

Kebhinnekaan Indonesia dibanggakan, tetapi belum dilembagakan sepenuhnya karena komunikasi sering hanya berlangsung dalam komunitas masing-masing. Kalaupun komunikasi lintas komunitas berlangsung, sering kali itu hanya seremonial karena prasangka dan curiga masih mendominasi alam pikiran kita. Interaksi antarwarga negara dengan mindset silo (terisolasi) akan gagal mewujudkan motto "kebhinnekaan adalah anugerah" karena gagal menjadikannya sebagai modal sosial yang produktif.

Berbagai ilmuwan sosial dan antropolog bahasa berulang kali menyatakan, Indonesia adalah negara yang paling plural atau majemuk di dunia, terutama dari aspek suku-bangsa dan bahasa. Menurut data Badan Pusat Statistik (BPS) tahun 2010, Indonesia memiliki 1.340 suku-bangsa dengan 1.158 bahasa daerah. Tidak ada negara di dunia ini yang memiliki tingkat keragaman seperti di Indonesia. Bukan hanya suku-bangsa dan agama saja, agama dan kepercayaan juga cukup banyak di Indonesia, baik yang lokal maupun yang transnasional.

Pluralitas dan kompleksitas bangsa Indonesia semakin bertambah dengan eksistensi ormas, parpol, ideologi, busana, mazhab pemikiran, aliran dan sekte agama, serta ekspresi keberagamaan masing-masing umat beragama. Semua itu layak dibanggakan dan dirayakan, bukan dikoyak-koyak dengan kebencian dan pembohongan-pembohongan informasi yang memecah-belah. Publik harus benar-benar didorong untuk memahami bahwa pluralitas Indonesia bersifat natural dan kultural. Dengan kata lain, pluralitas atau kemajemukan itu sesuatu yang bersifat natural sekaligus juga bersifat kultural. Ia bisa dikatakan "natural" karena pluralitas merupakan fakta sosial yang tidak bisa terbantahkan sejak zaman pra-modern sampai zaman modern saat ini.

Pluralitas juga bersifat "kultural" karena merupakan bagian dari produk kebudayaan manusia. Artinya, manusia juga turut menciptakan pluralitas itu. Manusialah yang menciptakan aneka sistem sosial-politik-ekonomi, ilmu pengetahuan dan teknologi, tradisi dan budaya, bahasa, tata busana, ideologi, dan seterusnya sehingga menambah pluralitas masyarakat itu semakin bertambah plural. Berbeda dengan kelompok "primata bukan manusia" (nonhuman primates), kelompok "primata manusia" (human primates) pada dasarnya adalah makhluk yang sangat dinamis, maju, progresif, dan memiliki kecenderungan untuk terus berevolusi menjadi lebih baik di masa mendatang, dengan menciptakan sesuatu yang baru di berbagai bidang kehidupan.

Dunia pendidikan menjadi tempat potensial untuk menyemai nilai-nilai keberagaman dengan materi dan kurikulum multikultural. Di lembaga pendidikan perspektif intelektual anak didik dibentuk. Menurut Bennett, ada empat nilai inti atau core values dari pendidikan multikultural. Pertama, apresiasi terhadap multikultural. Kedua, 
pengakuan terhadap harkat manusia dan hak asasi manusia. Ketiga, pengembangan tanggung jawab masyarakat dunia. Dan keempat, pengembangan tanggung jawab manusia terhadap planet bumi. Lebih dari itu, menurut Bennet, ada enam tujuan pendidikan multikultural yang berkaitan dengan nilai-nilai inti tersebut. Yang pertama, mengembangkan perspektif sejarah (etnohistorisitas) yang beragam dari kelompokkelompok masyarakat. Kedua, memperkuat kesadaran budaya yang hidup di masyarakat. Ketiga, memperkuat kompetensi interkultural dari budaya-budaya yang hidup di masyarakat. Keempat, membasmi rasisme, seksisme, dan berbagai jenis prasangka. Adapun kelima, mengembangkan kesadaran atas kepemilikan planet bumi. Dan Keenam, mengembangkan keterampilan aksi sosial.

Sebelum dikenal apa yang disebut multikulturisme di Barat, jauh berabad-abad yang lalu bangsa Indonesia sudah memiliki falsafah "Bhinneka Tunggal Ika". Sejarah juga membuktikan bahwa semakin banyak suatu bangsa menerima warisan kemajemukan, maka semakin toleran bangsa tersebut terhadap kehadiran "yang lain". (Pimpinan MPR dan Tim Kerja Sosialisasi MPR RI, 2016: 185).

Sejak Indonesia merdeka, para pendiri bangsa dengan dukungan penuh seluruh rakyat Indonesia bersepakat mencantumkan kalimat Bhinneka Tunggal Ika pada lambang Negara Garuda Pancasila yang ditulis dengan huruf latin pada pita putih yang dicengkeram burung garuda. Semboyan tersebut berasal dari bahasa Jawa Kuno yang berarti "Berbeda-beda tetapi tetap satu jua" dengan makna semboyan pemersatu wilayah Nusantara. Dengan demikian, kesadaran akan hidup bersama di dalam keberagaman sudah tumbuh dan menjadi jiwa serta semangat peserta didik bangsa, jauh sebelum zaman modern. (MPR RI, 2016: 186-187).

Allah swt. menciptakan manusia bersuku-suku dan berbangsa-bangsa supaya saling mengenal. Firman Allah dalam Q.s. al-Hujurat/49: 13. Terjemahnya:

Wahai manusia! Sungguh, Kami telah menciptakan kamu dari seorang laki-laki dan seorang perempuan, kemudian Kami jadikan kamu berbangsa-bangsa dan bersuku-suku agar kamu saling mengenal. Sungguh, yang paling mulia di antara kamu di sisi Allah ialah orang yang paling bertakwa. Sungguh, Allah Maha Mengetahui, Maha Teliti.

Bangsa Indonesia sebagai bangsa yang majemuk; memiliki jumlah penduduk yang cukup besar, memiliki bahasa daerah yang berbeda-beda, mempunyai suku bangsa yang beragam, mempunyai agama yang berbeda-beda, warna kulit bermacam-macam, adat istiadat, dan banyak lagi perbedaan lainnya, melahirkan semboyan yang mengungkapkan rasa persatuan dan kesatuan yang berasal dari keanekaragaman. (MPR RI, 2016: 67)

Dengan demikian, jelaslah bahwa kemajemukan/keberagaman yang telah menjadi sunnatullah tidak mungkin dihindari, tetapi perlu dirawat agar dapat menjadi dinamika kehidupan yang mengasyikkan dengan saling menghargai dan menghormati antara sesama anak bangsa. 


\section{Persatuan}

Persatuan adalah tiang penyangga daya suatu negara. Kemajuan atau kemunduran suatu negara ditentukan oleh persatuan dan kesatuan bangsanya. Bangsa yang makmur adalah bangsa yang bersatu sedangkan bangsa yang hancur adalah bangsa yang berseteru. Indonesia adalah bangsa yang terdiri atas berbagai macam ras, suku dan agama. Tentu terdapat banyak perbedaan di dalamnya. Namun dalam keberagaman itu kita bersatu dalam semboyan Bhinneka Tunggal Ika, berbeda-beda tetapi tetap satu jua. itulah hal dasar yang merupakan tiang kokoh bangsa kita. Untuk meningkatkan citra bangsa di mata dunia kita perlu mempertahankan keberagaman dengan persatuan dan kesatuan yang selama ini kita bina. Pandangan Islam dalam menanggapi perbedaan, sesungguhnya sesuai kodrat penciptaan manusia berbangsa-bangsa dan bersuku-suku supaya saling mengenal. Firman Allah dalam Q.s. al-Hujurat/49: 13

Terjemahnya: Wahai manusia! Sungguh, Kami telah menciptakan kamu dari seorang laki-laki dan seorang perempuan, kemudian Kami jadikan kamu berbangsabangsa dan bersuku-suku agar kamu saling mengenal. Sungguh, yang paling mulia di antara kamu di sisi Allah ialah orang yang paling bertakwa. Sungguh, Allah Maha Mengetahui, Maha Teliti.

Allah swt. mengisyaratkan agar kita semua memperkokoh persatuan dan kesatuan dan melarang untuk bercerai berai. Ini terangkai dalam Qur'an surat Ali 'Imran/3: 103

Terjemahnya: Dan berpeganglah kamu semuanya kepada tali (agama) Allah, dan janganlah kamu bercerai berai, dan ingatlah akan ni`mat Allah kepadamu ketika kamu dahulu (masa Jahiliyah) bermusuh musuhan, maka Allah mempersatukan hatimu, lalu menjadilah kamu karena ni mat Allah orang-orang yang bersaudara; dan kamu telah berada di tepi jurang neraka, lalu Allah menyelamatkan kamu daripadanya. Demikianlah Allah menerangkan ayat-ayat-Nya kepadamu, agar kamu mendapat petunjuk.

Ayat tersebut memotivasi kita agar perbedaaan ideologi, organisasi, agama, adat istiadat, suku bangsa, dan bahasa harus menjadi jembatan emas guna memperkokoh persatuan dan kesatuan bangsa. Oleh karena itu, mulai detik ini kita samakan langkah, seragamkan gerak, satukan persepsi, berat sama dipikul, ringan sama dijinjing. Perbedaan jangan melahirkan perpecahan, tapi hendaknya perbedaan menjadikan kita harus saling menghargai dan melengkapi. Lalu jika kita lihat keadaan bangsa kita sekarang ini, dari Sabang sampai Merauke, terdapat sebuah pertanyaan besar. Bagaimanakah kekompakan di negeri kita sekarang? Alhamdulillah seiring dengan semangat gotong royong, seirama dengan semangat bhinneka tunggal ika, berbeda-beda tapi satu jua, perbedaan persepsi dan visi dalam pembangunan masih dirasakan sebagai ف ف اسد ت بـ قوا ال خ يرات berlombalomba dalam kebaikan. Berkompetisi dalam kebaikan adalah merupakan realisasi dari firman Allah swt. dalam Q.s. al-Maidah/5: 48

Terjemahnya:...Kalau Allah menghendaki, niscaya kamu dijadikan-Nya satu umat (saja), tetapi Allah hendak menguji kamu terhadap karunia yang telah diberikan-Nya kepadamu, maka berlomba-lombalah berbuat kebajikan. Hanya kepada Allah kamu 
semua kembali, lalu diberitahukan-Nya kepadamu terhadap apa yang dahulu kamu perselisihkan.

\section{Penanaman Nilai-Nilai Kebangsaan}

Dalam KMA Nomor 184 Tahun 2019 pada BAB IV ayat 3 disebutkan bahwa Pengembangan muatan lokal mendukung terwujudnya empat pilar kebangsaan Republik Indonesia (Pancasila, UUD 1945, NKRI, dan Bhinneka Tunggal Ika). Muatan lokal dimaksudkan untuk membentuk pemahaman peserta didik terhadap keunggulan dan kearifan di daerah tempat tinggalnya. Pada Bab V ayat 1 disebutkan pula bahwa Madrasah menyelenggarakan kegiatan ekstrakurikuler sebagai suplemen dari usaha pengembangan potensi, bakat, minat dan karakter peserta didik. Dan pada ayat 3 Pramuka menjadi kegiatan ekstrakurikuler wajib. Selanjutnya pada ayat 4 disebutkan bahwa Kegiatan ekstrakurikuler meliputi: Usaha Kesehatan Sekolah (UKS), Palang Merah Remaja (PMR), PASKIBRA, olah raga, seni, pengembangan riset dan teknologi, komunikasi, pembinaan olimpiade/kompetisi sains,pecinta alam, keagamaan Islam, keputrian, pengembangan bahasa, kewirausahaan dan kegiatan lain yang menjadi keunggulan madrasah.

\section{E. Penananaman Nilai-Nilai Kebhinekaan}

Globalisasi memiliki peran sentral dalam meningkatkan gerakan-gerakan radikalisasi massa. Nilai-nilai kebangsaan harus ditanamkan pada para peserta didik dan atau santri di pondok Pesantren. Pondok pesantren adalah lembaga pendidikan Islam tertua yang merupakan produk budaya Indonesia dan telah lama eksis di negeri ini. Semakin besar efek yang ditimbulkan globalisasi, maka nilai-nilai kebangsaan Indonesia akan terpinggirkan bahkan terancam. Pandangan masyarakat yang seolah-olah bahwa pesantren lekat dengan teroris dan anti nasionalisme, harus dihilangkan.

Derasnya arus globalisasi menyebabkan nilai-nilai kebangsaan dapat dikatakan semakin dilupakan keberadaannya. Salah satu masalah utama adalah masalah identitas kebangsaan. Dengan derasnya arus globalisasi dikhawatirkan budaya bangsa khususnya nilai-nilai kebangsaan dan budaya lokal mulai terkikis. Budaya asing kian mewabah dan mulai mengikis eksitensi budaya bangsa dan nilai-nilai nasional yang sarat makna. Agar eksistensi budaya bangsa tetap kukuh diperlukan upaya mempertahankan identitas bangsa yang dikarenakan fenomena peserta didik lebih menyukai dan bangga dengan budaya budaya asing dari pada budaya asli bangsanya sendiri. Hal ini dibuktikan dengan adanya rasa bangga yang lebih pada diri anak manakala menggunakan produk luar negeri dibandingkan jika menggunakan produk bangsa sendiri.

Generasi muda adalah salah satu aset Indonesia pada masa yang akan datang. Bangsa Indonesia harus mampu menempatkan generasinya untuk menjadi pemimpin di masa mendatang. Hal tersebut harus ada upaya untuk menanamkan nilai-nilai kebangsaan sebagai ciri khas budaya bangsa untuk membedakan dengan orang lain di negera ini. Selain itu adanya budaya lokal yang melekat pada diri peserta didik di sekolah akan mampu memperkuat jati diri sebagai bangsa Indonesia. Masalah ini merupakan suatu 
fakta yang tidak boleh diabaikan mengingat pentingnnya sikap nasionalisme dalam memajukan Negara Indonesia. Terkait dengan penanaman nilai kebangsaan di era global ini, salah satu lembaga formal yang ikut bertanggung jawab adalah satuan pendidikan formal yang turut membantu tugas pendidikan informal. Sekolah dapat dikatakan sebagai rumah kedua. Di sekolah dan asrama selain mendapatkan pendidikan akademik, peserta didik juga mendapatkan pendidikan moral dan spiritual, karena itu sekolah dan asrama menjadi salah satu wadah yang tepat untuk menanamkan nilai-nilai kebangsaan kepada peserta didik. Dalam hal ini guru dan pembina asrama mempunyai peran yang sangat penting.

Menanamkan nilai-nilai kebangsaan di sekolah dan asrama menjadi salah satu upaya untuk membentuk peserta didiknya menjadi warga negera yang berkarakter, karena dengan pendidikan dapat menyiapkan generasi muda untuk memegang peranan untuk kehidupan bangsa di masa mendatang. Namun kenyataanya di sekolah masih ditemukan peserta didik yang kurang memahami negara dan bangsanya sendiri dan kurang disiplin.

Berdasarkan pemaparan di atas, maka peneliti beranggapan bahwa penanaman nilai-nilai nasionalisme dalam lingkup kehidupan sehari-hari dirasakan masih perlu untuk diperkuat lagi eksistensinya khususnya di sekolah atau madrasah agar peserta didik atau santri dapat mengamalkan nilai-nilai nasionalisme, selain itu juga agar jati diri bangsa Indonesia yang ada dari dulu, dapat tertanam dengan baik pada diri setiap santrinya.

\section{F. Faktor yang Mempengaruhi Wawasan Kebangsaan Peserta Didik}

Menurut UU No. 20 Tahun 2003 tentang sistem Pendidikan Nasional, pendidikan adalah usaha sadar dan terencana untuk mewujudkan suasana belajar dan proses pembelajaran agar peserta didik secara aktif mengembangkan potensi dirinya untuk memiliki kekuatan spiritual keagamaan, pengembangan diri, kepribadian, kecerdasan, akhlak mulia, serta keterampilan yang diperlukan dirinya, masyarakat, bangsa dan negera.

Terdapat beberapa faktor yang mempengaruhi pendidikan dalam menanamkan wawasan kebangsaan pada peserta didik diklasifikasikan menjadi dua, yaitu faktor intern dan faktor ekstern. Adapun yang dimaksud dengan faktor intern adalah faktor yang berasal dari dalam diri individu. Sedangkan faktor ekstern adalah faktor yang berasal dari luar individu. Adapun faktor-faktor yang dimaksud dapat memengaruhi wawasan kebangsaan peserta didik adalah:

\section{Faktor intern, terdapat beberapa faktor yang terdiri dari:}

a. Faktor jasmaniah yang berupa faktor kesehatan. Di mana dalam aktivitas peserta didik akan tergangggu jika kondisi fisiknya kurang sehat. Dan pada nantinya akan berpengaruh terhadap kehidupannya. Untuk itu, agar seseorang dapat menyerap nilai-nilai dengan baik, maka hendaklah bisa menjaga kondisi fisiknya agar tetap sehat dan segar, sehingga bisa melaksanakan aktivitas dengan baik dan benar.

b. Faktor psikologis. Peserta didik sebagai manusia yang memiliki perbedaan dalam kemampuan, bakat, minat, motivasi, watak, ketahanan, semangat, dan sebagainya. 
Dalam berbagai ciri itu peserta didik yang lebih unggul pada hampir ke semua ciri yang dapat disebutkan, ada pula yang unggul pada sebagian ciri tertentu. Sedangkan pada ciri yang lainnya lemah, keadaan tersebut dapat membatasi kelangsungan dan hasil pendidikan

\section{Faktor ekstern, terdiri dari:}

a. Faktor keluarga; Keluarga merupakan masyarakat dalam bentuk kecil yang terdiri dari bapak, ibu, dan anak. seiring dengan pertumbuhannya, maka anak akan menerima pengaruh dari keluarganya, baik itu positif maupun negatif. Menurut Dewa Ketut Sukardi (1988: 59), dijelaskan bahwa faktor lingkungan keluarga meliputi orang tua, suasana rumah dan keadaan sosial ekonomi keluarga.

b. Faktor sekolah; Faktor sekolah yang dapat memengaruhi wawasan kebangsaan peserta didik, bisa berupa: Metode mengajar, lingkungan, kondisi, sarana prasarana pendidikan, dan yang sangat berpengaruh adalah kompetensi kepribadian dan sosial pendidik dan tenaga kependidikan di sekolah.

c. Faktor masyarakat; selain di rumah dan di sekolah, lingkungan masyarakat tempat peserta didik bergaul cukup besar pengaruhnya terhadap jati diri, watak dan krakter seseorang; berupa: perkumpulan remaja, karang taruna, penyaluran bakat dan minat, organisasi pemuda, dan lain-lain.

\section{G. Memelihara Toleransi}

Toleransi dalam masyarakat majemuk dirasa penting, untuk terus menjaga silaturrahim warga yang memiliki latar belakang kehidupan yang sangat beragam dari segi suku, bahasa, budaya dan agama yang ada di NKRI. Dalam menjaga toloransi masyarakat majemuk, sering kali di beberapa tempat dan situasi karena alasan tertentu, mungkin solidaritas, kedaerahan, agama, organisasi, dan sebagainya - akhirnya keberagaman dikorbankan, baik dalam pesta demokrasi seperti Pilkada maupun dalam situasi lainnya. Kita berharap generasi muda dapat membentengi diri dari segala pengaruh negatif yang ada saat ini, termasuk memelihara toleransi di masyarakat. Kita hidup dalam masyarakat yang majemuk yang kaya keanekaragaman, hal tersebut harus menjadi nilai positif bagi kita. Dalam penegakan hukum dikenal Pro Justicia kepolisian melakukan penyelidikan dan penyidik, dan Restorative Justice di mana alternatif hukum menjadi pilihan.

UU tentang toleransi pertama UU 1/1965 tentang penodaan agama hukuman 5 Tahun penjara. UU 40/2008 penghapusan diskriminasi, ras dan etnis hukuman 5 Tahun dan denda Rp 500 juta. UU 11/2008 tentang informasi dan transaksi elektronik hukuman 6 Tahun, dan denda Rp 1 Milyar. Semua hukuman yang ada adalah melanjutkan yang tertuang dalam undang-undang, di mana setiap hukuman tidak sama. Toleransi biasanya berhubungan dengan SARA di mana suku, agama, ras dan antar golongan yang tergabung dalam kebhinnekaan.

Tragedi Sampit 2001 Dayak vs Madura, tragedi Ambon 1999 Muslim vs Kristen, tragedi Nasional 1998 Cina vs Pribumi, kejadian-kejadian tersebut menjadi pelajaran 
berharga bagi kita semua, agar ke depan saudara-saudara kita tidak menjadi korban di kemudian hari. Oleh karena itu, kami pihak kepolisian berharap semua generasi muda, dapat terus menjaga tolerasi antar suku, ras, agama dan golongan yang selama ini sudah terjaga dengan baik. Dalam toleransi pemecahan masalah secara kekeluargaan harus dikedepankan, sehingga adat dan budaya kita orang timur tetap terjaga.

Sikap toleransi dan menghargai tidak hanya berlaku terhadap orang lain, terhadap yang berbeda agama dan keyakinan juga tetap mengenal toleransi. Dalam menyikapi keberagaman wajib dilandasi nilai-nilai Pancasila, UUD 1945, NKRI dan Bhinneka Tunggal Ika. Negara Indonesia berdasarkan Ketuhanan Yang Maha Esa, dengan demikian konteks kehidupan berbangsa dan bernegara haruslah berlandaskan nilai-nilai ketuhanan. Di sisi lain, toleransi dari prespektif kaum muda, pemuda menurut undang-undang 40 Tahun 2009 WNI yang berusia 16-36 tahun. Toleransi sikap yang saling memiliki dan menghargai perekat dan pengikat kerukunan bangsa. Potensi konflik dan tantangan di mana kita merupakan negara kepulauan yang memiliki keragaman dalam segala hal.

Nilai-nilai agama dan budaya perlu dijadikan sumber etika dalam berbangsa dan bernegara. Semua agama mengajarkan tentang kebaikan. Nilai-nilai agama harus dijadikan sebagai sumber etika dan moral, agar generasi muda memiliki acuan yang jelas dalam menjaga persatuan dan kesatuan. Terjadinya konfik sosial budaya karena salah dalam mengartikan toleransi, selain itu kesenjangan ekonomi, praktik birokrasi yang diwarnai KKN, praktik demokrasi yang mencampuradukan kepentingan pribadi dan kelompoknya dapat menjadi pemicu ketegangan dan pertentangan batin bagi generasi muda anak bangsa. Toleransi dari prespektif kaum muda menjadikan nilai-nilai agama dan budaya sebagai sumber etika kehidupan dalam rangka memperkuat akhlak dan moral. Sejarah perjuangan Bangsa Indonesia telah mencatat peran penting, sebagai garda terdepan bangsa ini. Toleransi merupakan kebutuhan mutlak dalam kehidupan bermasyarakat.

\section{HASIL PENELITIAN DAN PEMBAHASAN}

\section{Proses Penanaman Nilai-nilai Kebangsaan dan kebhinnekaan pada Peserta didik.}

Sekolah/madrasah merupakan lembaga pendidikan yang sangat efektif dalam menanamkan nilai-nilai kebangsaan pada peserta didik, sehingga peserta didik memiliki karakter baik yang nantinya akan bermanfaat dalam kehidupannya di masa yang akan datang. Pendidikan yang menekankan pada pembentukan kepribadian sejatinya telah dilaksanakan oleh MA Madani Alauddin karena pada dasarnya tujuan pendidikan adalah menciptakan manusia yang unggul dalam ilmu pengetahuan dan teknologi serta akhlak mulia, sehingga pelaksanaan pendidikan oleh setiap sekolah tentunya mengacu pada tercapainya hal tersebut. 
MA Madani Alauddin mempunyai visi yaitu "MENJADI PUSAT UNGGULAN PEMBENTUKAN DAN PEMBINAAN SUMBER DAYA MANUSIA YANG MENGUASAI ILMU PENGETAHUAN (AGAMA DAN UMUM), TEKNOLOGI DAN MEMILIKI AHKLAK YANG TERPUJI"

MA Madani Alauddin juga memiliki misi: (a) Meningkatkan kualitas peserta didik dalam bidang ilmu agama dan umum serta teknologi. (b) Meningkatkan kemampuan peserta didik dalam bidang penguasaan bahasa asing (Arab dan Inggris), (c) Membiasakan peserta didik mengamalkan nilai-nilai akhlak al-karimah. (d) Meningkatkan kualitas tenaga pendidik dalam rangka peningkatan kualitas pembelajaran. (d) Menyiapkan sarana pendidikan yang memadai.

Penanaman nilai kebangsaan di MA Madani Alauddin bukan merupakan sebuah mata pelajaran berdiri sendiri. Tetapi lebih kepada pengintegrasian sekumpulan nilai-nilai kebangsaan melalui berbagai cara, yaitu pengintegrasian dalam pembelajaran, kegiatan ekstrakurikuler, serta dalam budaya atau pembiasaan peserta didik di sekolah.

Dari hasil observasi dapat diketahui bahwa dalam lingkungan sekolah sangat mementingkan nilai-nilai kebangsaan pada peserta didik. MA Madani Alauddin berusaha untuk mengembangkan nilai-nilai kebangsaan agar dapat membentuk jiwa dan kepribadian anak agar siap dalam menghadapi tantangan global yang diintegrasikan melalui kegiatan pembelajaran PKn dan kegiatan ekstrakurikuler.

\section{a. Kegiatan Pembelajaran PKN}

Strategi yang digunakan melalui mata pelajaran PKn ini merupakan mata pelajaran yang memfokuskan pada pembentukan warga negera yang memahami dan mampu melaksanakan hak dan kewajiban dengan cerdas sebagai warga negera Indonesia yang berkarakter kebangsaan. Dengan menanamkan nilai-nilai kebangsaan pada peserta didik seperti nilai-nilai religius, kejujuran, kedisiplinan, mandiri, cinta tanah air, kerja sama dan penduli lingkungan pada peserta didik, sehingga diharapkan menjadi warga negera yang baik dan mencerminkan karakter bangsa yang berbudi luhur. Dalam kegiatan pembelajaran mata pelajaran PKn dengan waktu 2 jam dalam sepekan atau diberikan satu kali pertemuan sungguh kurang memadai. Alokasi waktu tersebut sangat terbatas, namun dalam proses penanaman nilai kebangsaan pada peserta didik yang diintegrasikan melalui mata pelajaran PKn berusaha melaksanakan pembelajaran dan penanaman nilai kebangsaan dengan baik. Guru berusaha memberikan pembelajaran yang menarik dan mengandung nilai-nilai nasionalisme, namun sesekali guru tidak bisa hadir dan sebagai gantinya peserta didik diberikan tugas dengan berdiskusi dan mengemukakan pendapat

\section{b. Kegiatan Ekstrakurikuler}

Pengembangan diri (ekstrakurikuler) merupakan kegiatan yang bertujuan untuk menggali potensi yang dimiliki oleh peserta didik MA Madani Alauddin, dengan adanya kegiatan ini peserta didik akan memiliki pengalaman serta wawasan yang lebih luas, yang tidak mereka dapatkan dalam kegiatan pembelajarandi kelas. Kegiatan ini sangat 
penting bagi peserta didik terutama dalam hal penanaman nilai-nilai kebangsaan pada peserta didik. Dalam organisasi intra sekolah terdapat beberapa kegiatan ekstrakurikuler yang berfungsi sebagai penyalur potensi yang dimiliki oleh peserta didik. Cinta Tanah Air.

Dalam upaya menginternalisasikan nilai-nilai kebangsaan pada peserta didik, asrama dan sekolah merupakan wadah yang paling tepat dalam membentuk sikap cinta tanah air pada generasi sekarang ini dengan melalui kegiatan-kegiatan yang terprogram, terutama kegiatan ekstrakurikuler. Kegiatan-kegiatan ekstrakurikuler ini dirancang untuk mengembangkan rasa cinta tanah air, maka tidak diragukan lagi sumbangannya terhadap pengembangan pendidikan nilai kebangsaan dan kebhinnekaan.

Kegiatan wajib yakni ekstrakurikuler pramuka, peserta didik begitu antusias saat pembina mengarahkan mereka untuk baris berbaris. Selain itu, peserta didik juga diajak untuk menyanyikan lagu-lagu kebangsaan Indonesia raya. Hal ini dilakukan untuk meneguhkan rasa cinta peserta didik kepada tanah air Indonesia sejak dini. Melalui lagulagu kebangsaan diharapkan dapat menumbuh kembangkan semangat kebangsaan dan cinta tanah air.

Dalam kegiatan rutin melaksanakan upacara setiap hari Senin dan hari-hari besar nasional lainnya di dalamnya terdapat hormat bendera merah putih. Bendera sekalipun hanya berupa kain merah yang dipadu dengan kain putih, tetapi bendera tersebut merupakan simbol dan lambang NKRI sebagai hasil perjuangan kusuma bangsa meraih kemerdekaan, sehingga hormat bendera bukanlah sekedar menghormati kain, namun merupakan perwujudan cinta tanah air dan sebagai bukti kesediaan menjaga persatuan dan kesatuan bangsa Indonesia. Bendera merah putih adalah lambang negera dan pemersatu bangsa, sehingga harus dikenalkan dan dibiasakan kepada peserta didik untuk hormat kepada sang merah putih. Selain itu, guru PKn dan pembina juga selalu menekankan kepada peserta didik agar mengingat dan menghargai perjuangan para pahlawan dalam melawan penjajah.

\section{Kesadaran Berbangsa dan Benegara}

Kesadaran berbangsa dan bernegera dalam kegiatan-kegiatan yang ada di lingkungan asrama dan sekolah seperti kegiatan ekstrakurikuler, dan kegiatan-kegiatan rutin, spontan dan terprogram lainnya di MA Madani Alauddin dapat dilihat dari para pembina yang mengharuskan peserta didik berbicara menggunakan bahasa Indonesia yang baik dan benar. Hal ini dapat menjadikan peserta didik terbiasa untuk memakai bahasa persatuan yaitu Bahasa Indonesia baik ketika mengikuti kegiatan-kegiatan di sekolah ataupun di lingkungan masyarakat.

\section{Faktor pendukung dalam menanamkan nilai kebangsaan dan kebhinnekaan pada peserta didik}

Dalam menanamkan nilai kebangsaan pada peserta didik yang diintegrasikan melalui pembelajaran PKn, kegiatan ekstrakurikuler, dan pembiasaan atau budaya 
sekolah maupun asrama, intinya adalah untuk menanamkan nilai-nilai kewajiban terhadap Tuhan, negera, dan terhadap sesama, serta diri sendiri seperti halnya yang tercantum dalam buku pedoman MA Madani Alauddin. Untuk mencapai hasil yang optimal dibutuhkan dukungan dari lingkungan sekolah maupun dari luar sekolah serta pihak stake holder baik yang bersifat materil maupun moril sangat dibutuhkan guna terlaksananya dengan lancar penanaman nilai-nilai kebangsaan kepada peserta didik.

\section{Faktor penghambat dalam menanamkan nilai kebangsaan dan kebhinnekaan pada peserta didik}

Pelakanaan penanaman nilai-nilai kebangsaan pada peserta didik di asrama MA Madani Alauddin menemui beberapa hambatan. Hambatan tersebut di antaranya adalah peserta didik dari latar belakang keluarga yang berbeda-beda, sehingga dalam berperilakupun ada beberapa peserta didik yang membutuhkan perhatian khusus dari para pembina asrama dan guru.

\section{Upaya mengatasi faktor penghambat dalam menanamkan nilai kebangsaan dan kebhinnekaan pada peserta didik}

Mengingat pentingnya penanaman nilai kebangsaan pada peserta didik guna membangun sumber daya manusia yang kuat, diperlukannya penanaman nilai kebangsaan yang tepat pada peserta didik. Dapat dikatakan bahwa pembentukan nilai kebangsaan merupakan sesuatu yang tidak dapat dipisahkan dari kehidupan. Maka dari itu, terdapat dua nilai utama yang menjadi pilar pendidik dalam membangun karakter kebangsaan peserta didik yang kuat untuk anak didiknya yaitu amanah dan keteladanan.

Terbentuknya karakter kebangsaan peserta didik memerlukan proses yang relatif lama dan terus menerus. Oleh karena itu, sejak masa dini harus ditanamkan nilai-nilai kebangsaan pada anak. Kegiatan-kegiatan yang dilakukan di sekolah juga dapat membentuk karakter kebangsaan, karena pembiasaan kegiatan yang dilakukan diarahkan pada upaya untuk pembudayaan pada aktivitas tertentu sehingga menjadi aktivitas yang terpola dan tersistem. Guru (pendidik) memiliki andil besar terhadap penanaman nilai kebangsaan pada peserta didik. Oleh karena itu, penampilan dan sifat-sifat pendidik harus ke arah pembentukan karakter kebangsaan yang kuat.

Dalam menanamkan nilai-nilai kebangsaan dan kebhinnekaan pada peserta didik ditemui beberapa faktor penghambat, faktor penghambat tersebut adalah karakter peserta didik dari latar belakang keluarga yang berbeda-beda, dan peserta didik belum bisa membagi waktu untuk kegiatan di sekolah dengan baik dan terbatasnya sarana dan prasarana.

Upaya mengatasi hambatan dalam menanamkan nilai kebangsaan dan kebhinnekaan pada peserta didik, para guru sering mengadakan problem solving dengan tujuan agar peserta didik selalu terbuka dengan pendidik dan peserta didik bisa hidup bersama-sama dan saling menghargai antar budaya dan suku. 


\section{SIMPULAN}

Berdasarkan rumusan masalah, hasil penelitian dan pembahasan serta temuan penelitian yang sudah dilakukan, maka diambil kesimpulan sebagai berikut:

1. Dalam proses penanaman nilai-nilai kebangsaan dan kebhinnekaan pada peserta didik di tengah arus globalisasi di MA Madani Alauddin dilakukan melalui berbagai cara untuk menumbuhkan kembali identitas bangsa pada peserta didik. Hal ini ditumbuhkan dan dintegrasikan melalui pembelajaran PKn di kelas, kegiatan ekstrakurikuler (pengembangan diri), serta mengadakan kegiatankegiatan positif di sekolah untuk menunjang jiwa kebangsaan peserta didik.

2. Faktor pendukung dalam menanamkan nilai-nilai kebangsaan dan kebhinnekaan pada peserta didik di antaranya adalah kerjasama pihak sekolah yakni kepala sekolah dan guru dalam memberikan contoh atau keteladanan yang baik kepada peserta didik, minat peserta didik dalam mengikuti kegiatan ekstrakurikuler di sekolah, sarana dan prasarana yang mencukupi. Hal ini dapat dilihat dari kelengkapan fasilitas yang menunjang dalam proses pembelajaran di sekolah, serta dukungan dari orang tua peserta didik yang menginginkan anaknya berada di lingkungan sekolah yang disiplin. Sedangkan faktor penghambat dalam menanamkan nilai kebangsaan pada peserta didik di antaranya adalah karakter peserta didik dari latar belakang keluarga yang berbeda-beda, dan peserta didik belum bisa membagi waktu untuk kegiatan di sekolah dengan baik.

3. Solusi untuk mengatasi hambatan dalam menanamkan nilai-nilai kebangsaan dan kebhinnekaan pada peserta didik adalah para guru mengadakan problem solving dengan upaya memotivasi peserta didik untuk saling menghargai antar sesama, pihak sekolah yakni kepala sekolah dan guru mengadakan evaluasi setiap semester kepada peserta didik untuk melihat perkembangan peserta didik, serta memberikan sanksi kepada peserta didik berupa poin bagi yang melanggar peraturan sekolah.

Berdasarkan penelitian yang telah dilakukan, maka peneliti mempunyai beberapa saran yaitu pihak sekolah perlu mengadakan semacam pelatihan atau training secara intensif terkait dengan pengintegrasian nilai kebangsaan ke dalam kegiatan di sekolah, seperti adanya pemberian materi yang berisikan motivasi, seperti adanya tanya jawab yang nantinya ada pemberian nilai bagi yang bisa menjawab dengan benar, dan lain sebagainya. 


\section{DAFTAR PUSTAKA}

Ali, Mursyid (ed.). 2009. Pemetaan Abd Azis Albone. (2006). Pendidikan agama Islam dalam perspektif multikulturalisme. Jakarta: Balai Penelitian dan Pengembangan Agama Jakarta.

Agus Iswanto. (2008). Pendidikan agama dalam perspektif multikulturalisme "integrasi PAI dan PKN mengupayakan PAI yang berwawasan multikulturalisme”. Jakarta : Saada Cipta Mandiri.

Andreas Doweng, dkk. (2012). Pancasila Kekuatan Pembebas. Yogyakarta : PT Kanisius.

Arsy Karima Zahra. (2008). Pemelihan Program Belajar yang Baik. Di akses dari www. Arsykarimazahra. Blogspot.com. Pada tanggal 4 Februari 2015. Jam 10. 20

A . Malik M. Thaha Tuanaya, dkk. (2007). Modernisasi Pesantren. Jakarta: Balai Penelitian dan Pengembangan Agama.

Benedict Anderson. (1999). Nasionalisme "Imagined Communities" (terjemahan Prof. Mr. Sunaryo).

Badri, Yatim. (1999). Soekarno, Islam, dan Nasionalisme. Jakarta: Logos Wacana Ilmu.

Bambang, Daroeso. (1986). Dasar dan Konsep Pendidikan Moral Pancasila. Semarang: Aneka Ilmu.

Dewa Ketut Sukardi. (1988). Bimbingan dan Konseling. Jakarta: PT Bina Aksara.

Dian purnama. (2010). Cermat memilih sekolah menengah yang tepat. Jakarta : Penerbit Gaga Smedia.

Dwi Siswoyo, dkk. (2011). Ilmu Pendidikan. Yogyakarta : UNY press.

Djumahur \& Moh. Suryo. (1985). Bimbingan dan Penyuluhan di Sekolah (Guidance and Counseling). Bandung : Penerbit C. V ilmu

Ernest Renan. (1947). What is the Nation (terjemahan Prof. Mr. Sunaryo).

Iskandar Engku \& Siti Zubaidah. (2014). Sejarah Pendidikan Islam. Bandung: PT Remaja Rosdakarya.

Jazim Hamidi \& Mustafa Lutfi. (2010). Civic Education Antara Realitas Politik dan Implemantasi Hukumannya. Jakarta : PT Gramedia Pustaka Utama.

Creswell, John W. (2015), Qualitative Inquiry \& Research Design: Choosing Among Five Appoaches, Diterjemahkan Oleh Ahmad Lintang Lazuardi dengan Judul: Penelitian Kualitatif dan Desain Riset; Memilih di antara Lima Pendekatan. Yogyakarta: Pustaka Pelajar. 
Emzir. (2008), Metodologi Penelitian Pendidikan Kuantitatif dan Kualitatif. Jakarta: RajaGrafindo Persada.

Moleong, Lexy J. (2016), Metodologi Penelitian Kualitatif. Bandung: Remaja Rosdakarya.

Majelis Permusyawaratan Rakyat RI. (2016), Bahan Tayang Materi Sosialisasi Empat Pilar MPR RI. Jakarta: Sekretariat Jenderal MPR RI.

Pimpinan MPR dan Tim Kerja Sosialisasi MPR RI. (2016), Materi Sosialisasi Empat Pilar MPR RI. Jakarta: Sekretariat Jenderal MPR RI.

Sugiyono. Metode Penelitian Kuantitatif, Kualitatif, dan Kombinasi (Mixed Methods). (2017), Bandung: Alfabeta.

Sulaiman Saat dan Sitti Mania. (2019), Pengantar Metodologi Penelitian; Panduan bagi Peneliti Pemula. Gowa: Pustaka Al-Maida.

Santana K., Septiawan. Menulis Ilmiah Metode Penelitian Kualitatif. (2007), Jakarta: Yayasan Obor Indonesia. 